\title{
Mathematical Approaches in Studying Stress
}

\author{
Sorin Pricope ${ }^{1}$, Sabina Irimie ${ }^{2}$ and Luminița Muntean ${ }^{3}$ \\ 1, 2, 3University of Petroșani, Petroșani, Romania
}

Correspondence should be addressed to: Sabina Irimie; sabina.irimie@gmail.com

Received date: 10 September 2015; Accepted date: 12 january 2016; Published date: 10 March 2016

Academic Editor: Mihail Busu

Copyright (c) 2016. Sorin Pricope, Sabina Irimie and Luminița Muntean. Distributed under Creative Commons CC-BY 4.0

\begin{abstract}
Occupational stress is a global phenomenon that concerns employees, employers and specialists from various fields: psychologists, sociologists, doctors, engineers, economists, hygiene specialists and last but not least mathematicians. If economists have calculated the costs of this phenomenon by showing influences on the productivity, profit, the mathematicians analyze from statistical point of view and formulate laws of variation. This paper illustrates such a concern, part of a broader research on the stress in the mining sector.
\end{abstract}

Keywords: occupational stress, mining field, mathematical quantification, law of variation

\section{Introduction}

The world is changing due to several factors, from technological progress to active life time increase, from rushing for resources to huge gaps between the rich and the poor, from climate change to population aging, from global to national specific. All this and more so are the challenges for the world of work. One of the important problems of the global world today is the psychosocial risks that are perceived as more challenging than others, according to the Second European Survey of Enterprises on New and Emerging Risks - ESENER-2 in 2014 (EU-OSHA 2015a). Psychosocial risks and occupational /organizational stress in particular are problems studied by many specialists
(Anisman 2014; Băban 1998; Bodea 2012; Cooper, and Marshall 1976; Cox, 1978; Cox and Griffiths 2010; EU-OSHA 2000; Floru 1974; Golu 1981; Holt 1982; Kalimo, Lindström, and Smith 1997; Lazarus and Folkman 1984; Spielberger 2010).The literature has defined and identified some theories and factors associated with stress (the Demand-Control theory of Karasek (1979), the Person-Environment Fit theory of French, Caplan and Van Harrison (1982), the Transactional theories of Lazarus (1990)).

Stress, whose pioneer is Hans Selye (1956) and named it for the first time in the socalled "general adaptation syndrome" and describes it as a reaction of biological

Cite this Article as: Sorin Pricope, Sabina Irimie and Luminița Muntean (2016), "Mathematical Approaches in Studying Stress", Journal of Eastern Europe Research in Business \& Economics, Vol. 2016 (2016),

Article ID 814896, DOI: 10.5171/2016. 814896 
organisms to stress, concerned more and more specialists over the time. Analyzed, the "general adaptation syndrome" consists of 3 phases: alarm phase, resistance phase (defense), burnout phase. Stress occurs whenever appears an outstanding imbalance between request and responsive possibilities of the body. The European Agency for Safety and Health at Work (EU-OSHA) defines "work-related stress is experienced when the demands of the work environment exceed the workers' ability to cope with (or control) them" (EU-OSHA 2012, p.21). In the paper National Standard Competences of Project Management Version 3.2 - Web defines stress as the" physical and psychic state of a person responding to a situation perceived as burdensome or threatening. Response to subjectively perceived stress is manifested on the level of experiencing, cognition, behavior and bodily symptoms" (Pitas et al. 2012, p.329). Stress is defined by the United Kingdom Health and Safety Executive (Health and Safety Executive UK), as a reaction of defense that people show in case of excessive pressure or other types of requirements addressed to them.

"A recent Eurobarometer survey by the European Commission found that 53\% of workers believe that stress is the main safety and health risk they face in the workplace, and $27 \%$ of workers reported experiencing 'stress, depression, anxiety' caused or worsened by work during the last 12 months" (2014, p.5). EU-OSHA's European Survey of Enterprises on New and Emerging Risks (ESENER) (2010) found that over 40\% of employers consider psychosocial risks more difficult to manage than 'traditional' occupational safety and health risks (EUOSHA 2013, p.6). In the European Union, stress affects $30 \%$ of the employees of the $\mathrm{EU}$, and in Europe more than 40 million people are affected by stress due to their place of work. Because of this, preventing stress at work constitutes one of the objectives set out in The Statement of European Commission regarding the new strategy in the field of safety and health at work. According to the World Health
Organization's Convention, stress at the workplace leads to discomfort and/or physical, mental and/or social malfunctioning. Stress in the workplace is responsible for millions of working days unused each year and for millions of sick leaves. Although it is difficult to determine how and how much it contributes in generating accidents at work, it is proven that stress competes in producing many events. Although the numbers which reflect the human and monetary losses are significant, many organizations do not have the magnitude of the problem (EU-OSHA 2014). "At the national level, the cost for businesses and society is estimated to run into billions of euros" (EU-OSHA 2015b, p.5).

That is why it is very important to analyze the phenomenon from a statistical point of view and from the laws of variation point of view, to determine trends in the evolution of the phenomenon. Moreover, interdisciplinary research ensures an overview of the phenomenon and the best measure to be taken. The present work is part of broader research through which it analyses the situation in the mining and energy sector, represents a novelty in terms of study and apprehends stress as a phenomenon at all viable JIU Valley mining and Branches of Deva Electric Power Factory and Paroșeni Electric Power Factory.

\section{Methodology and Aria of Research}

The pilot study of research, which we present in this paper, was prepared on the basis of the results obtained as a result of organizational stress questionnaire interpretation, administered during the period May-June 2015 from employees at Exploatarea Miniera Lonea (E.M. Lonea), branch of the Energetic Complex Hunedoara (CEH), one of the viable mines (Bodea,et al. 2015).

Morbidity is considered to be an essential indicator of health status it is representing the phenomenon of illness in a community over a period of time (Bodea, Bozdog \& 
Burdea 2013; Marica, Irimie \& Băleanu 2015). Knowing the economic and social effects of the disease, as well as the statistical data on the prevalence of occupational diseases, diseases related to chronic diseases, the indicators of morbidity with temporary incapacity for work (ITM) E.M. Lonea was chosen for the pilot study. The choice is based on the existing situation in E.M. Lonea, which according to the index of gravity is the place with the most days of the ITM, with most illnesses and diseases related profession, has index of gravity (IG) highest tumors, tuberculosis, Musculoskeletal diseases at CEH.

Research methodology uses questionnaire as an instrument of research. Organizational Stress Inventory questionnaire (O.S.I.) includes a battery of seven tests with corresponding assessment scale and each test has a different number of items (182 items total) adjusted to the level of understanding of the target group (Irimie et al. 2015, p.64). After collecting the applied questionnaires, processing was made on the basis of realizing a database and interpretation of the results obtained. The research area consists of 334 people, of which 77 subjects represents managerial staff (MS), quality certified by the professional risk assessment, as well as 257 subjects - execution staff, workers employed in various professions. Administered questionnaires were filled out correctly, so valid for 52 people in category MS and 103 people in the other category, the rest are partially completed questionnaires and are not valid in statistical processing. This situation is explicable through the great disadvantage of sociological inquest questionnaire based method to self- administration data collection. Category MS fits all leaders starting from the level of the mine director and up to the head of the brigade.

\section{The Interpretation of the Results}

Analysis of the demographic factors has taken into account several criteria for structuring the research area: average age, sex, marital status, family supporters, number of children, level of education, seniority, seniority in the workplace, the number of hours that are required to work per week, number of hours per week worked for real, who is the person who decides to work so many hours the post office, job and the level in hierarchy. Next, presenting and commenting some of those results.

- Considering the sex of subjects, a number of 52 decision makers are divided as follows: 32 subjects $(61.53 \%)$ male and 20 subjects (38.47\%) female. The share of about $40 \%$ of female staff is due to the inclusion of personnel TESA within the E.M. Lonea Staff.

- The average age of MS to this unit is 44.8 years, an advanced age for mining field.

- For the employees having a partner alongside, the question arises of whether this one works. Thus, 35 subjects $(67.30 \%)$ the partner is working and for the 17 subjects $(32.70 \%)$ do not work, so there is one sustainer in the family.

- Number of children notes that 23 subjects $(44.23 \%)$ have 1 child, 9 subjects $(17.30 \%)$ have 2 kids and the rest of the 20 subjects $(38.46 \%)$ are childless (Figure 1). 


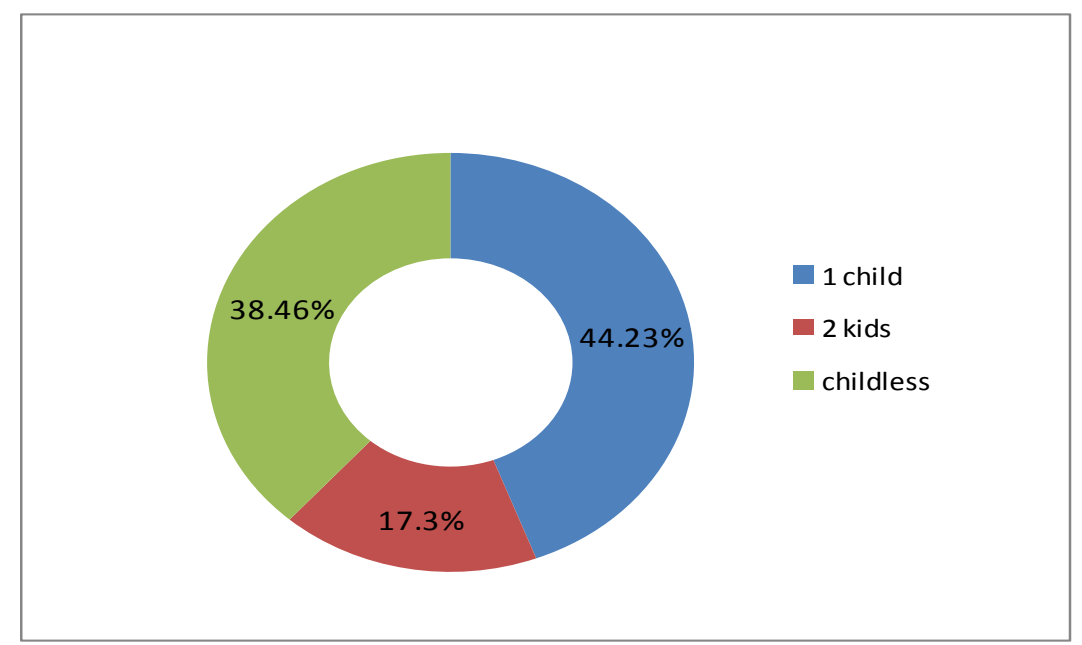

Source: authors

Figure 1: Number of children

- The level of professional training for MS reflects a good training: 4 subjects $(7.69 \%)$ secondary-school studies, $28 \quad(53.84 \%)$ subjects the licensing studies, 18 subjects (34.61\%) masters degrees and 2 subjects (3.84\%) other studies (Figure 2 ).

\section{Source: authors}

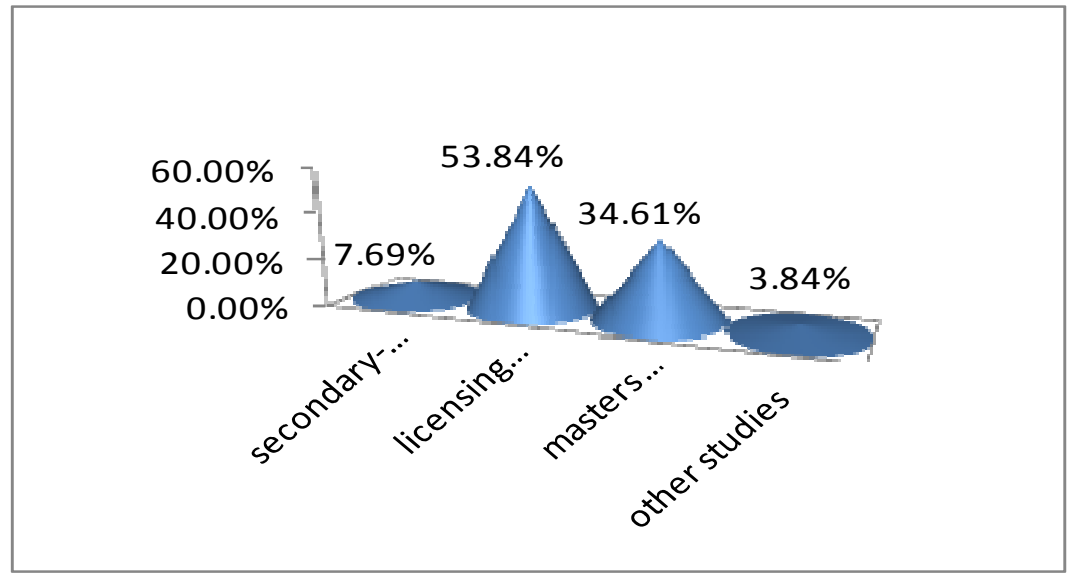

Figure 2: The level of professional training

- In relation to the years of service of MS the following is observed: 2 subjects (3.84\%) have a length of service between $0-5$ years, 3 subjects (5.76\%) have a length between 6-10 years, 3 subjects $(5.76 \%)$ have a length between $11-15$ years, 4 subjects (7.69\%) have a length between 16-20 years, 16 subjects $(30.76 \%)$ have a length of between 21-25 years and 24 subjects (46.15\%) have a length of over 25 years, which indicates that the vast majority is nearing retirement/leaving the system (Figure 3). 


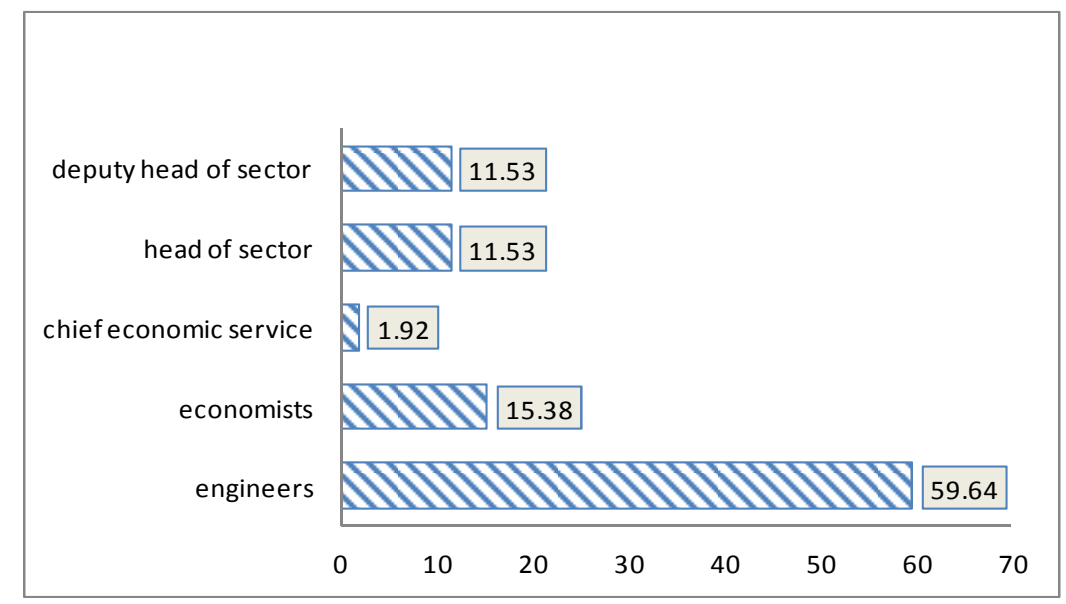

Source: authors

Figure 3: Years of service of subjects MS

- After seniority at this working place the situation of the subjects is as follows: 4 subjects (7.9\%) have a length between $0-5$ years, 4 subjects $(7.69 \%)$ have a length between 6-10 years, 6 subjects (11.53\%) have a length between 11-15 years, 5 subjects $(9.61 \%)$ have a length between 16 20 years, 15 subjects $(28.40 \%)$ have a length of between 21-25 years and 18 subjects (34.61\%) had a length of over 25 years in the workplace, which indicates that the vast majority of subjects is approaching retirement/ leaving the system.
- Distribution of subjects MS according to their occupation or the level of hierarchy is situated is as follows: 30 (59.64\%) engineers, $9(15.38 \%)$ are economists, $1(1.92 \%)$ is chief economic service, $6(11.53 \%)$ head of sector and $6(11.53 \%)$ deputy head of sector (Figure 4).

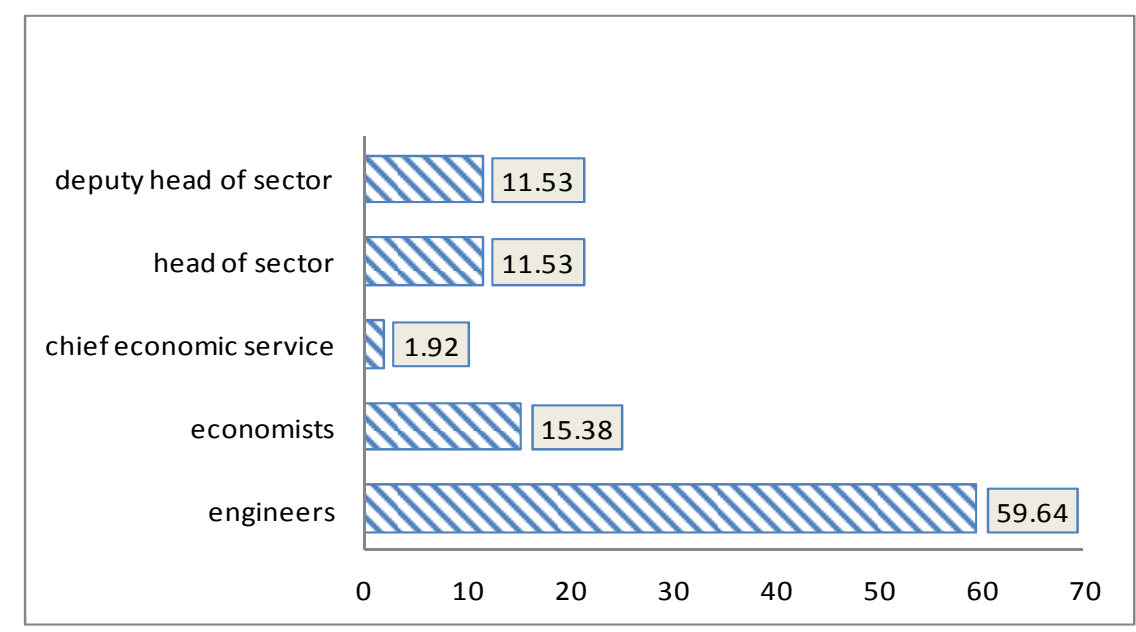

Figure 4: Distribution of subjects MS according to their occupation Source: authors

Sorin Pricope, Sabina Irimie and Luminița Muntean (2016), Journal of Eastern Europe Research in Business \& Economics, DOI: 10.5171/2016. 814896 
Our analysis refers to MS and is successively following the items of the questionnaire from chapter 1 , highlighting significant items in terms of the results obtained.

The chapter relating to the professional satisfaction shall be considered as a scale of assessment for all the items analyzed: $1=$ very much satisfaction; $2=\mathrm{a}$ lot of satisfaction; $3=$ neither satisfaction nor user dissatisfaction; 4 = a lot of dissatisfaction; $5=$ very much dissatisfaction.

In terms of communication and the way the information circulate in the workplace, it accounted for $40 \%$ of the subjects polled who said they had a lot of satisfaction and more than a third who do not have any problem communicating in the workplace, havingcommunication problems, however, accounts for about $10 \%$ of MS. The work carried out in the present day brings a lot of satisfaction to almost half the population of MS, confirmed the percentage response $19.23 \%$ very much satisfaction (Figure 5). We can generally affirm that the capacity to have a decision at work is not considered a problem from their perspective.

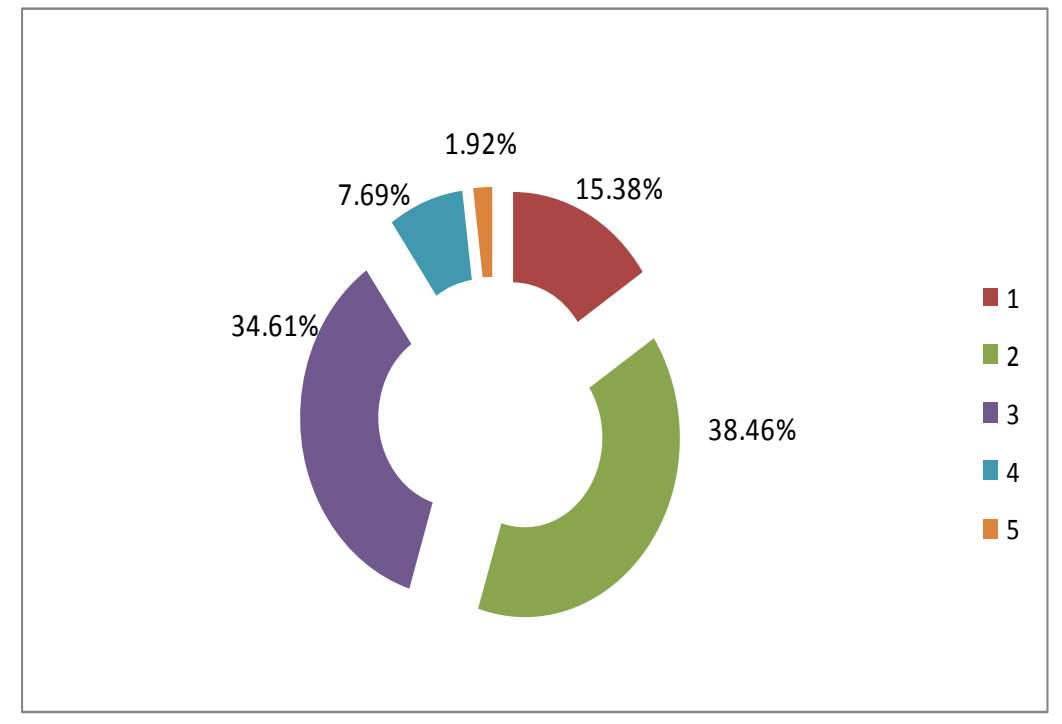

Figure 5: Perception on the communication and the way the information circulates at the workplace

Source: authors

The leadership style used by seniors is categorized by lower hierarchical MS levels as thankful-for over $44 \%$ of subjects, bizarre situation for the outsiders, since the situation in mining is known as not being in line with the cohesion of the subjects investigated (Figure 6). 21.15\% leadership style of the superiors produces plenty and little dissatisfaction. 


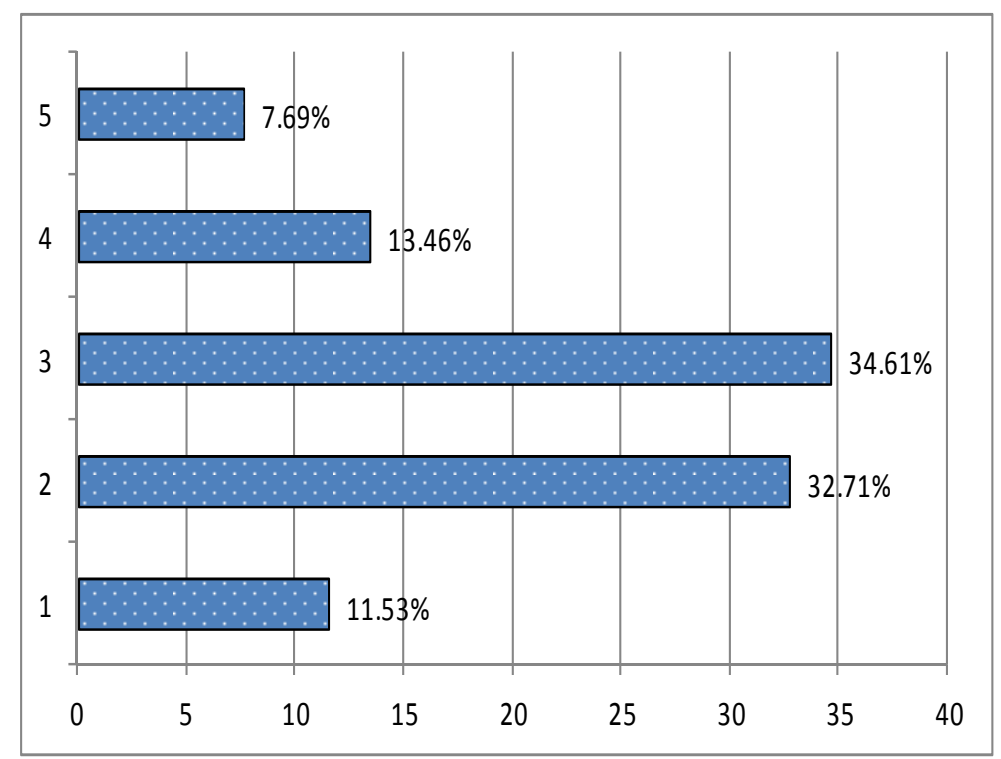

Figure 6: Appreciation of the leadership style used by seniors

Source: authors

MS respond to the item "the extent to which they feel involved in the activity" at a rate of almost $62 \%$ that they are satisfied with the results, adversarial situation of their work results, which leads us to believe that their perception of the current situation is social desirable, that they don't have the courage to affirm the reality felt. This disguises the real existing situation- a continuous stress linked to the possibility of loss of job and fear of showing that cannot cope with the situation. From a psychological point of view, their goal is to keep self-respect and opinion that we should have about ourselves, to defuse psychological traumatic moments. It is about the psychological defense mechanisms that enable elimination or specific interpretation of unpleasant information, reducing the feeling level of anxiety that occurs as a result of awareness of inner conflict (Figure 7).

In terms of psychological atmosphere or climate existing in the workplace $65.38 \%$ of the population interviewed stated that they are satisfied, and more than one third of category MS asserts a lot of dissatisfaction and very much dissatisfaction. The most important sources of stress caused by organizational structure and organizational climate relates to burdensome accountability, especially accountability to others, lack of social support and lack of participation in decision-making. Individuals responsible toward others (responsibility translates into motivation, punishing, rewarding and communicating with subordinates) live elevated levels of stress. 


\section{Figure 7:}

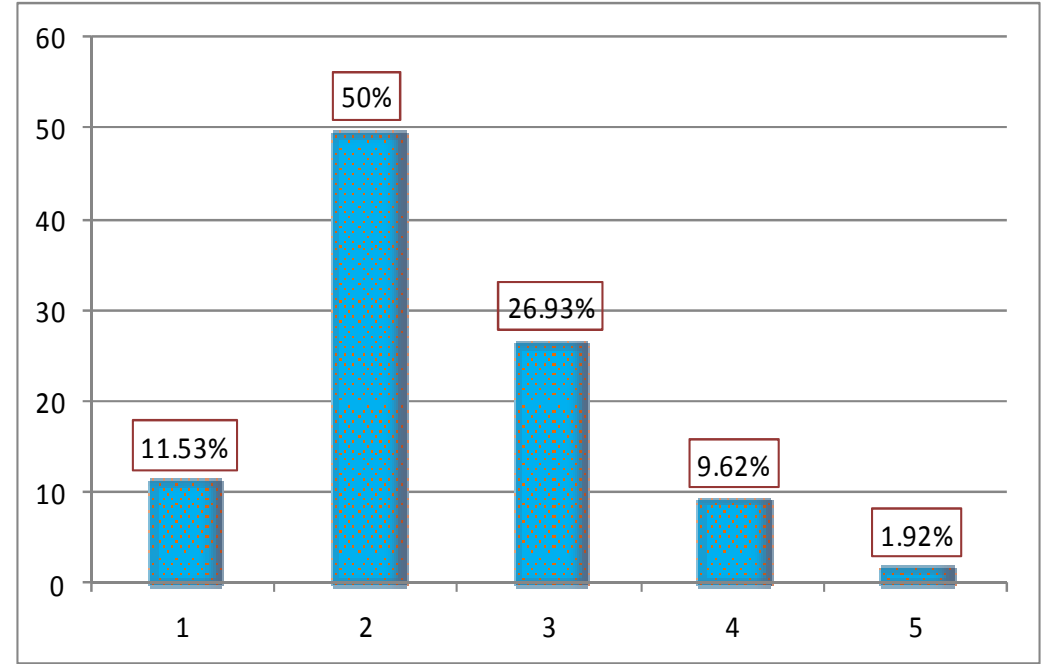

Source: authors

\section{Satisfaction determined by current work}

Surprisingly, today, like yesteryear, very few people are aware of the fact that stress is one of the biggest problems of our day most employers and employees consider stress as normal at work. Knowing the situation of investment in mining, damaging existing psychological climate in the workplace has as premium cause the lack of materials to carry out the work under normal conditions (Figure 8).

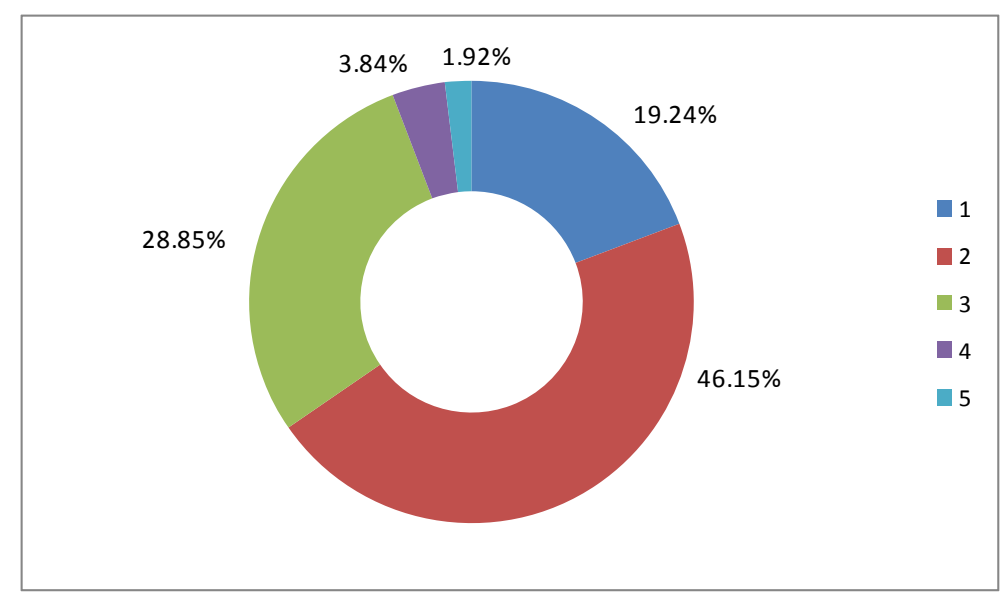

Source: authors

Figure 8: Psychological atmosphere or existing climate at your work place

\section{Mathematical Remarks}

To mathematically quantify the phenomenon surprised in Chapter 1, we will develop a functional matrix (52x12), consisting of 52
(52 subjects) and 12 columns (12 items), which will feature on each line answers to the 12 items with values from 1 to 5 in the given order from the test, the lines being 
overlapped in the interview order 52 subjects.

We determine from each interviewed decision-maker, a quotient resulted by levelheading the average of perfect squares, the replies given from 1 to 5 , to each of the 12 items in total 52 quotients -52 interviewed stakeholders, then by the arithmetic average of 52 such determined quotients, and produce a unique quotient. In our case it is
C1 $=2.615$. The average value is 3 , depending on this average value and the unique determined quotient, can conclude the trend of the phenomenon. Or in an another way: after plotting those 52 coefficients, figure 9, we shall determine by processing the experimental values of the resulting 52 quotients, the law of variation of the phenomenon and orthonormat radius $\mathrm{R}$ of graph for variation law as determined in figure 10.

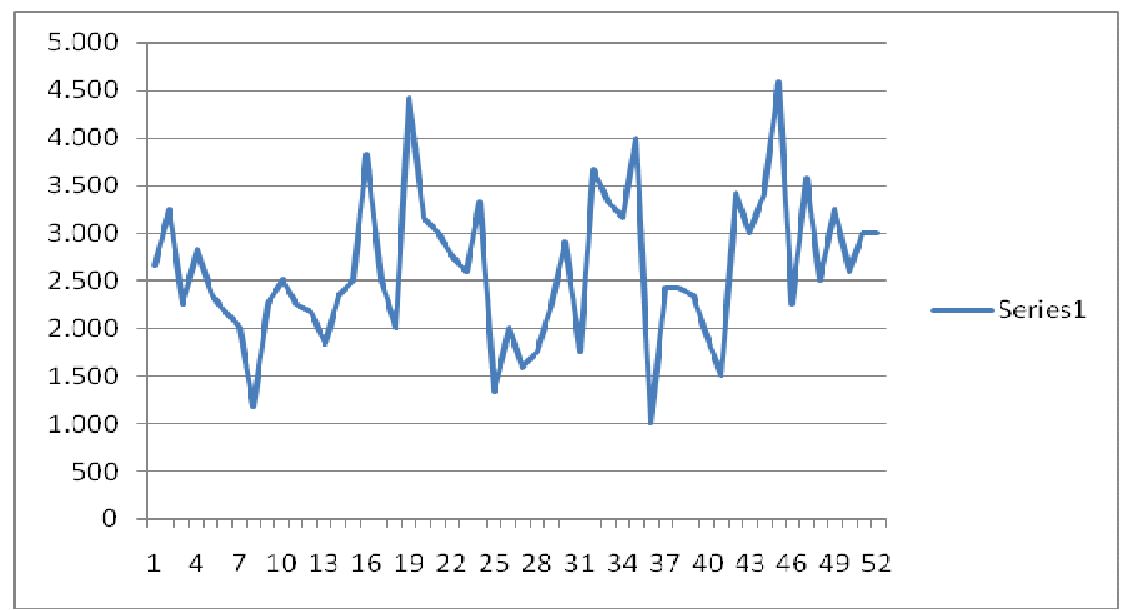

Source: authors

Figure 9: Variational formulation to the functional matrix

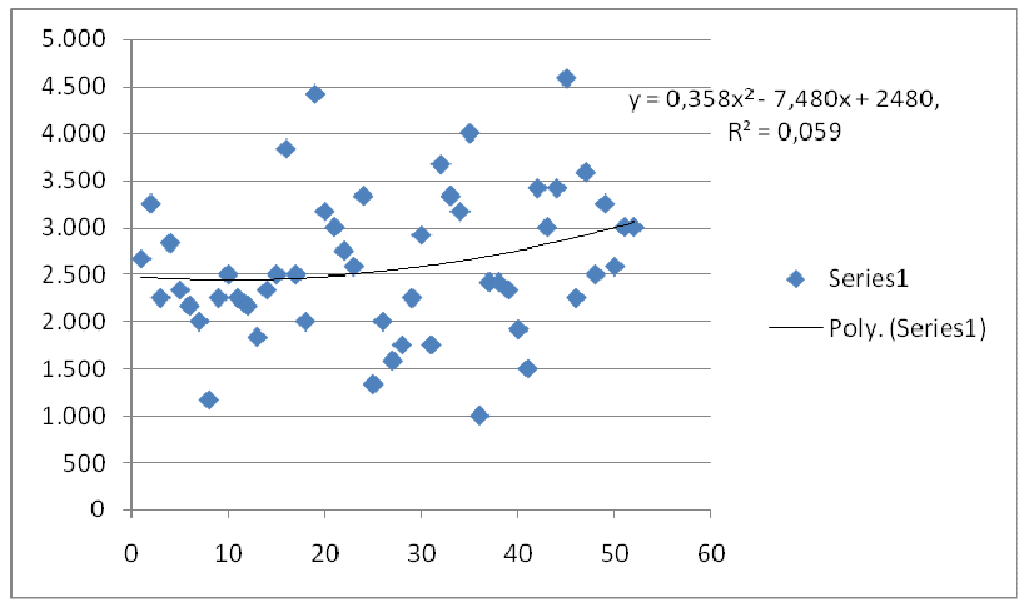

Source: authors

Figure 10: The law of change (variation)

Sorin Pricope, Sabina Irimie and Luminița Muntean (2016), Journal of Eastern Europe Research in Business \& Economics, DOI: 10.5171/2016. 814896 
This mathematical approach, i.e. the determination of the variation law of the phenomenon, indicates in an accurate way the trend of the phenomenon. The orthonormat radius $\mathrm{R}$ to the graph of variation law indicates the accuracy of the test.

52 level-headed quotients may be depicted in the chart/figure 11.

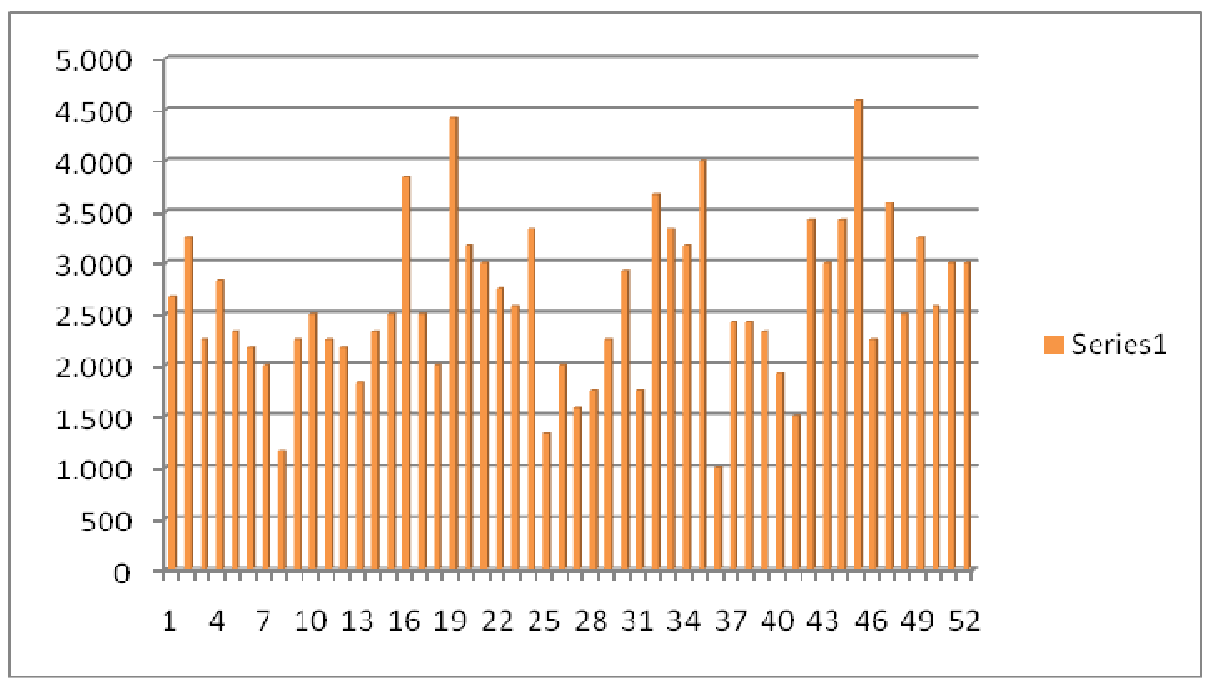

Source: authors

Figure 11: Variational formulation chapter 1 for Decision- makers c1 $=2.615$

In Figure 12 coefficient $\mathrm{C} 1=2.812$ is obtained by weighted average coefficient perfect squares and describes satisfaction at work for a single subject-factor decision - S1. This approach can be considered in relation to each individual, resulting as follows:

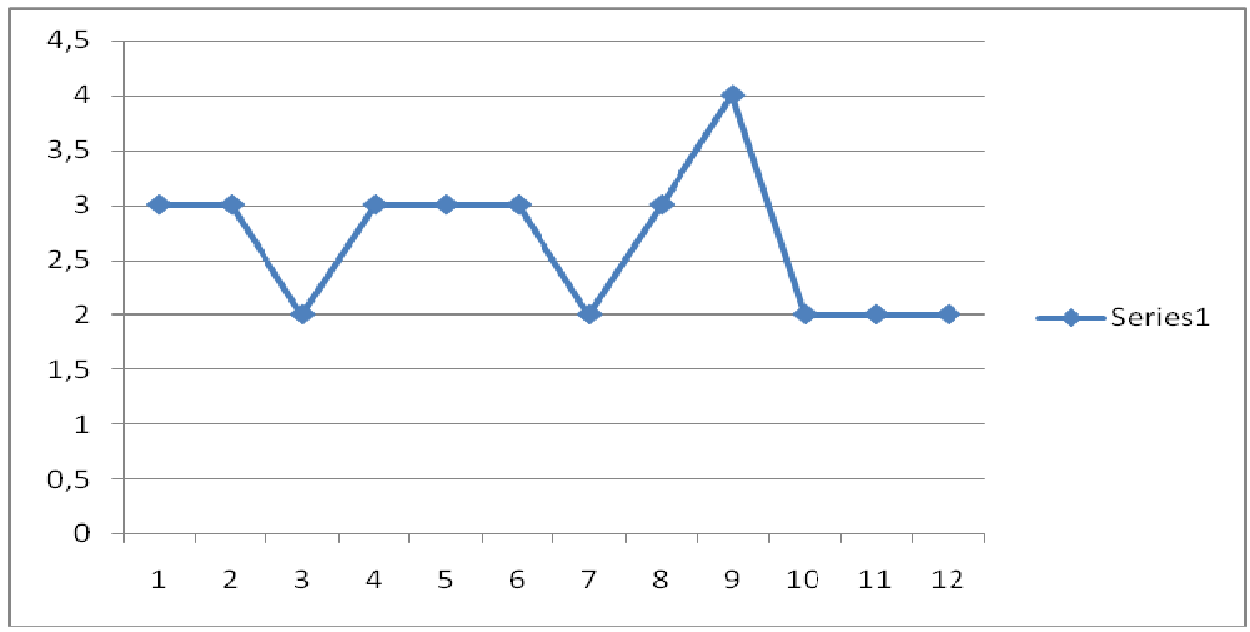

Source: authors

Figure 12: The graph of variation in satisfaction at work for S1 
We have a unique quotient, directly achieved from media of the perfect squares from the values of the 12 items, test no. 1 in the questionnaire, ranging from 1 to 5 in our case for a subject resulted following C1 individually $=2.812$ indicates a regression and figure 13 individually expresses more precisely the tendency of regression. Radius $\mathrm{R}$ indicates a high enough accuracy of the test. From Figure 13 shows that satisfaction at work is continuously dropping for this subject S1. This is also confirmed by the coefficient $\mathrm{C} 1=2.812$ and shape/allure graph showing the variation trends.

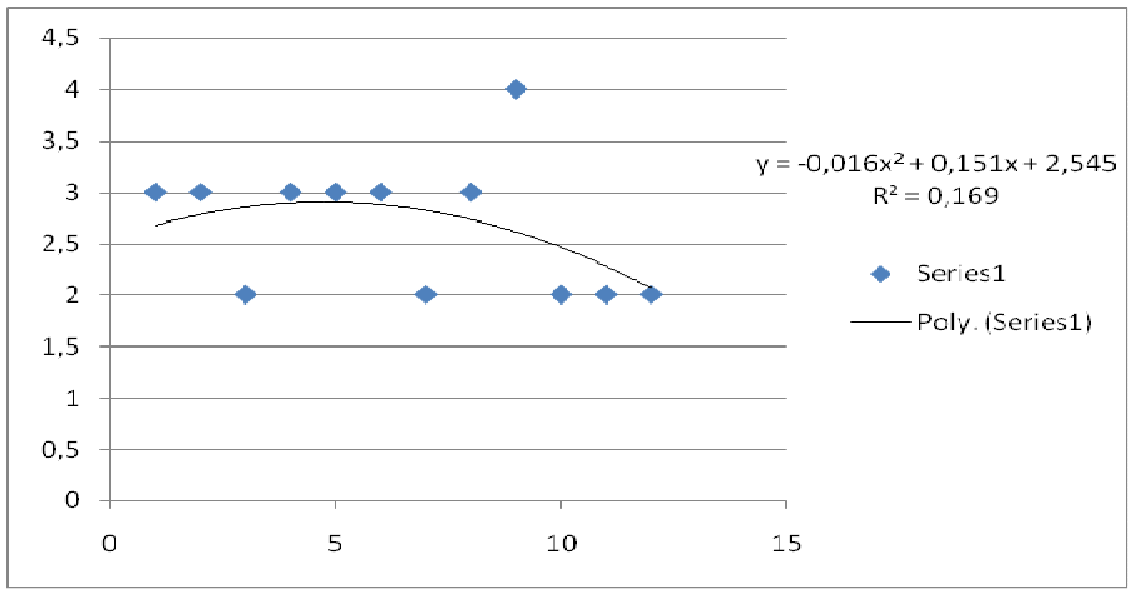

Source: authors

Figure 13: The law of change (variation)

Figure 14 describes the same phenomenon for subject S1 in an easily viewable manner.

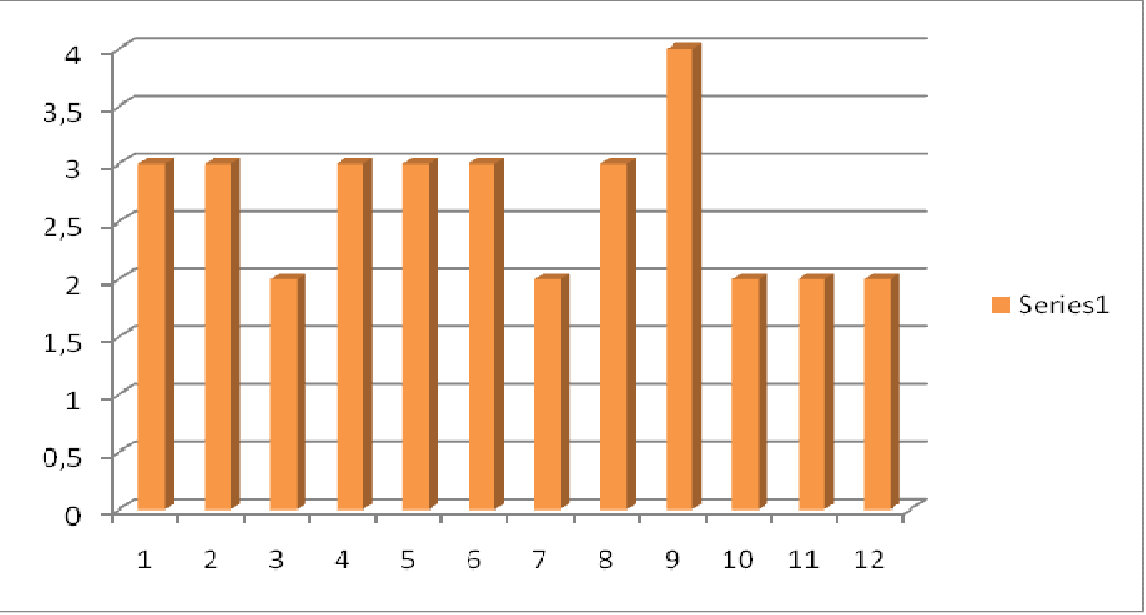

Figure 14: What do you think about your job? Variation formulation- Decision maker-a subject interviewed $\mathrm{c} 1=2.812$

Source: authors

The charts reflect variation law in all the 12 items of test 1 and subject S1 from the functional matrix, for concise approach in this paper. The research was carried out

Sorin Pricope, Sabina Irimie and Luminița Muntean (2016), Journal of Eastern Europe Research in Business \& Economics, DOI: 10.5171/2016. 814896 
using this approach for each topic deciding factor, and the whole set of subjects to describe a law of general variation. This law describes the phenomenon for the entire target group of decision makers.

To all the other chapters these mathematical approaches can be applied, quantification and determinations of the law of change of overtaken phenomenon by each chapter, an approach to determine the phenomenon for each individual subject and for the entire group of subjects also- the interviewed decision makers. It may be extended as to determine a quotient for all 7 chapters and for all subjects, and a unique variation law of the whole phenomena found in the 7 chapters for all decision makers interviewed subjects.

\section{Conclusions}

Ambiguous organizational stress is defined in certain literature through the hundreds of elaborate definitions is as a phenomenon often analyzed. In terms of organization, there are two types of stress: directconsequence of reducing the number of considered alternatives, less systematic analysis of alternatives, confusion in decision-making; and indirect- appearance of delays, absenteeism, accidents, negative moods in terms of communication.

Our pilot research study confirmed the hypothesis of the existence of stress factors that contribute to the deterioration of the situation of the sector concerned. After analyzing in mathematical manner it was observed the continuous regression to satisfaction makers - the group that has not sought and does not have its own tools and institutional support in solving and improvement actions. The solutions can be applied on several levels. At personal level it is solved through self-knowledge, identification and awareness of the problems. Everyone can self-manage and priorities the various factors generating stress/dissatisfaction. At the organizational level appears the need to create a department, served by trained personnel, to identify, manage and improve these factors. The local community / society through coherent policies and strategies of the mining, energy, economy in general, social work, health, education, culture, must increase the quality of life of those in the mining sector and their families.

The mathematical approach presented in the paper, can be a tool, a scientific support of institutional factors in solving the problem of stress both for subjects/individual, the whole group of decision on some factor of stress or the whole phenomenon of stress work.

The trends obtained by mathematical approaches can be very useful in forecasting studies, in developing strategies and measures to prevent stress.

\section{Acknowledgment}

"This paper was co-financed from the European Social Fund, through the Sectorial Operational Program- Human Resources Development 2007-2013, project number POSDRU/1871/1.5/S/155605 entitled "Scientific excellence, knowledge and innovation through doctoral programs in priority domains", beneficiary University of Petroșani".

\section{References}

1. Anisman, H. (2014) An Introduction to Stress and Health, Sage Publications Ltd.

2. Băban, A. (1998) Stresul și personalitatea, Editura Presa Universitară Clujeană, ClujNapoca.

3. Bodea, I. (2002). Importanța abordării problemelor psihosociale din mediul de muncă, Program twinning RO-IB-99-CO-01 România - Suedia, Timişul de Sus, Romania.

4. Bodea, I., Bozdog, A.F. and Burdea, F. (2013), Stresul, factor de risc important pentru sănătatea şi securitatea în muncă la minele din Valea Jiului, Conference "Jubiliară a Inspecției Muncii, Securitate și Sănătate în 
Muncă", 21-23 Octomber 2013, Sibiu, Romania.

5. Boldea, I., Irimie, S., Filip, E. and Muntean, L. (2015), Stress Analysis of Issues in the Mining Area, Conference 'Jubiliară a Inspecţiei Muncii, Securitate și Sănătate în Muncă", 19-21 October 2015, Timisoara, Romania

6. Cooper, C. L. and Marshall, J. (1976), 'Occupational sources of stress: a review of the literature relating to coronary heart disease and mental ill health', Journal of Occupational Psychology, 49, 11-28.

7. Cox, T. (1978) Stress, Macmillan, London.

8. Cox, T. and Griffiths, A. (2010), 'Workrelated stress: a theoretical perspective', in Leka, S. and Houdmont, J. (eds), Occupational Health Psychology, Wiley-Blackwell, Oxford.

9. European Agency for Safety and Health at Work (EU-OSHA). (2015a), European Survey of Enterprises on New and Emerging Risks (ESENER-2-2014) Luxembourg: Publications Office of the European Union. Available: <https://osha.europa.eu/en/surveys-andstatistics-osh/esener>.

[1 October 2015].

10. European Agency for Safety and Health at Work (EU-OSHA). (2015b), Healthy Workplaces Good Practice Awards 20142015. Managing stress and psychosocial risks at work, Luxembourg: Publications Office of the European Union. Available: <https://osha.europa.eu/ro/tools-andpublications/publications/reports/healthyworkplaces-good-practice-awards-20142015>.[1 October 2015].

11. European Agency for Safety and Health at Work (EU-OSHA). (2014), Calculating the costs of work-related stress and psychosocial risks - A literature review, Luxembourg: Publications Office of the European Union. Available:

$<$ https://osha.europa.eu/en/tools-andpublications/publications/literature_reviews /calculating-the-cost-of-work-related-stressand-psychosocial-risks>. [5 June 2015].

12. European Agency for Safety and Health at Work (EU-OSHA). (2012), Management of psychosocial risks at work: An analysis of the findings of the European Survey of Enterprises on New and Emerging Risks (ESENER), Luxembourg: Publications Office of the European Union. Available: <https://osha.europa.eu/en/publications/re ports/management-psychosocial-risksesener/view>. [5 June 2015].

13. European Agency for Safety and Health at Work (EU-OSHA). (2010), The European Survey of Enterprises on New and Emerging Risks (ESENER), Luxembourg: Publications Office of the European Union. Available: <https://osha.europa.eu/en/esenerenterprise-survey/enterprisesurveyesener>. [5 June 2015].

14. European Commission 2014. Eurobarometer 398 'Working Conditions'. Available from: <http://ec.europa.eu/public_opinion/flash/fl _398_sum_en.pdf>. [7 September 2015].

15.Floru, R. (1974) Stresul psihic, Ştiinţifică Publishing, Bucharest.

16. French, J. R. P., Caplan, R. D. and Van Harrison, R. (1982) The mechanisms of job stress and strain, Wiley \& Sons, New York.

17. Golu, M. (1981) Stresul psihic in Dicţionar de psihologie socială, Enciclopedică Publishing, Bucharest, pp. 235-236.

18. Health and Safety Executive UK (2009), How to tackle work-related stress. A guide for employers on making the Management Standards work, Available: <http://www.hse.gov.uk/pubns/indg430.pdf >. [8 September 2015].

19. Holt, R. (1982) 'Occupational Stress' in Goldberger, L. and Breznitz, S. (eds.), Handbook of stress. Theoretical and Clinical Aspects. The Free Press, New York, pp. 419444.

Sorin Pricope, Sabina Irimie and Luminița Muntean (2016), Journal of Eastern Europe Research in Business \& Economics, DOI: 10.5171/2016. 814896 
20. Irimie, S., Muntean, L., Pricope, S. and Irimie, I. S. (2015), 'Methodological aspects regarding the organizational stress analysis'. ACTA Universitatis Cibiniensis - Technical Series. [Online]. 66 (1), 61-66, doi: 10.1515/aucts-2015-0028. [Retrieved 12 October 2015], Available: <http://www.degruyter.com/view/j/aucts.2 015.66.issue-1/aucts-2015-0028/aucts2015-0028.xml?format=INT>.

21. Kalimo, R., Lindström, K. and Smith, M. J. (1997), 'Psychosocial approach in occupational stress', in Salvendy, G. (ed.), Handbook of human factors and ergonomics, Wiley, New York.

22. Karasek, R. A. Jr. (1979) 'Job demands, job decision latitude, and mental strain: implications for job redesign', Administrative Science Quarterly, 24, 285-308.

23. Lazarus, R. S. (1990) 'Theory-based stress measurement', Psychological Inquiry, 1, 3-13.
24. Lazarus, R. S. and Folkman, S. (1984) Stress, Appraisal and Coping, Springer Publishing, New York.

25. Marica, L., Irimie, S. and Băleanu, V. (2015). 'Aspects of Occupational Morbidity in the Mining Sector', Procedia Economics and Finance, [Online]. 23, 146-151, Elsevier. ScienceDirect, doi:10.1016/S22125671(15)00368-8, [Retrieved August 24, 2015],

Available:http://www.sciencedirect.com/sci ence/article/pii/S2212567115003688.

26. Pitas, J., Hajkr, J., Havlik, J., Machala, P., Motala, M., Novák, I. and Staníček, Z. (2012) National Standard Competences Of Project Management Version 3.2 - Web, ISBN 97880-260-2325-8, Publishing Společnost pro projektové ř́zení, o. s., Brno.

27. Selye, H. (1956) The stress of life, McGraw-Hill, New York.

28. Spielberger, C. D. (2010) Job Stress Survey. Corsini Encyclopedia of Psychology. 1. John Wiley \& Sons, Inc. 